Argonne Mational Laboratorn

\title{
CORROSION OF EXPERIMENTAL
}

THORIUM-BASE ALLOYS

$$
\text { by }
$$

James Y. N. Wang 


\section{DISCLAIMER}

This report was prepared as an account of work sponsored by an agency of the United States Government. Neither the United States Government nor any agency Thereof, nor any of their employees, makes any warranty, express or implied, or assumes any legal liability or responsibility for the accuracy, completeness, or usefulness of any information, apparatus, product, or process disclosed, or represents that its use would not infringe privately owned rights. Reference herein to any specific commercial product, process, or service by trade name, trademark, manufacturer, or otherwise does not necessarily constitute or imply its endorsement, recommendation, or favoring by the United States Government or any agency thereof. The views and opinions of authors expressed herein do not necessarily state or reflect those of the United States Government or any agency thereof. 


\section{DISCLAIMER}

Portions of this document may be illegible in electronic image products. Images are produced from the best available original document. 


\section{LEGAL NOTICE}

This report was prepared as an account of Government sponsored work. Neither the United States, nor the Commission, nor any person acting on behalf of the Commission:

A. Makes any warranty or representation, expressed or implied, with respect to the accuracy, completeness, or usefulness of the information contained in this report, or that the use of any information, apparatus, method, or process disclosed in this report may not infringe privately awnod righto; or

B. Assumes any liabilities with respect to the use of, or for damages resulting from the use of any intormation, apparatus, method, or process disclosed in this report.

As used in the above, "person acting on behalf of the Commission" includes any employee or contractor of the Commission, or employee of such contractor, to the extent that such employee or contractor of the Commission, or employee of such contractor prepares, disseminates, or provides access to, any information pursuant to his employment or contract with the Commission, or his employment with such contractor.

Printed in USA. Price $\$ 1.00$. Available from the Clearinghouse for Federal Scientific and Technical Information, National Bureau of Standards, U. S. Department of Commerce, Springfield, Virginia 
ANL-7006

Metals, Ceramics, and Materials

(TID-4500, 39th Ed.)

AEC Research and

Development Report

\author{
ARGONNE NATIONAL LABORATORY \\ 9700 South Cass Avenue \\ Argonne, Illinois 60440
}

\title{
CORROSION OF EXPERIMENTAL THORIUM-BASE ALLOYS
}

by

James Y. N. Wang

Metallurgy Division

Program 10.1.14

Work performed in 1960 - Report prepared February 1965

Portions of the material in this report have appeared in the following Metallurgy Division Annual Report:

$$
\text { ANL-6330 - pages } 114-117
$$

Operated by The University of Chicago under

Contract W-31-109-eng-38

with the

U. S. Atomic Energy Commission 
TABTLE OF CONTENTS

Page

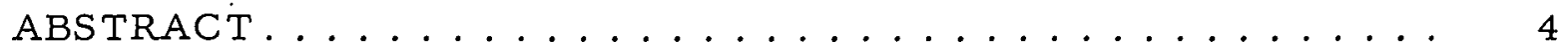

I. INTRODUCTION. ..................... 4

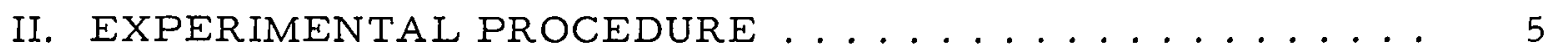

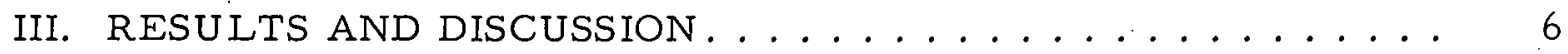

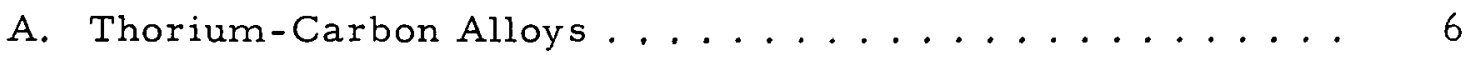

B. Thorium-Uranium Alloys .................. 7

C. Miscellaneous Alloys.................... 9

D. The Removal of Corrosion Products from Water-corroded

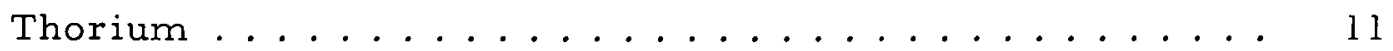

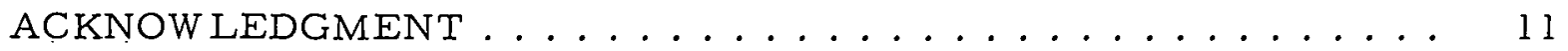

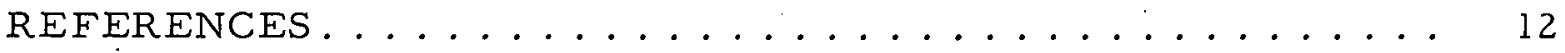




\section{LIST OF TABLES}

No.

Title

$\underline{\text { Page }}$

I. Analyses of Thorium. ................

II. Corrosion of Thorium-Carbon Base Alloys in Water

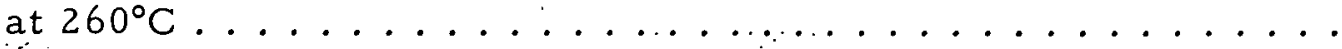

III. Corrosion of Thorium-Uranium Alloys Exposed in

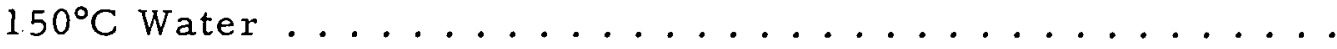

IV. Corrosion of Thorium-Uranium (Base) Alloys Exposed in

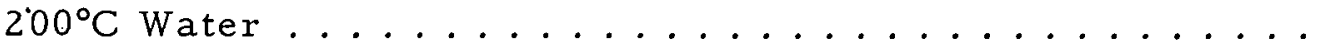

V. Corrosion of Miscellaneous Thorium-base Binary Alloys .... 10 


\section{CORROSION OF EXPERIMENTAI, THORIUM-BASE ALLOYS}

by

James Y. N. Wang

\section{ABSTRACT}

Some 50 high-purity, binary and ternary, thoriumbase alloys were prepared.and corrosion-tested in-distilled water between 120 and $260^{\circ} \mathrm{C}$.

During the relatively brief investigation, preliminary data indicated that the addition of titanium improved the corrosion life of $\mathrm{Th}-1 \mathrm{w} / \mathrm{OC}$ and $\mathrm{Th}-0.5 \mathrm{w} / \mathrm{oC}$ binary alloys at $260^{\circ} \mathrm{C}$. Additions of aluminum from 3 to $7 \mathrm{w} / \mathrm{o}$ appeared to be beneficial. At $200^{\circ} \mathrm{C}$, a Th- $10 \mathrm{w} / \mathrm{oY}$ alloy exhibited a low corrosion rate during a short period of exposure.

The corrosion resistance of all thorium-uranium alloys in increments of $5 \mathrm{w} / \mathrm{o}$ uranium, to the maximum $40 \mathrm{w} / \mathrm{o}$ uranium, was poor. The addition of $4 \mathrm{w} / \mathrm{o}$ zirconium to $\mathrm{Th}-1.5 \mathrm{w} / \mathrm{OU}$ caused an improvement at $200^{\circ} \mathrm{C}$.

\section{INTRODUCTION}

Thorium is more plentiful than uranium and has long been considered a potentially valuable source of secondary nuclear fuel for nuclear power reactors. Neutron irradiation of thorium produces uranium-233 and thereby increases the supply of fissionable material as atomic fuel. Since the corrosion resistance of thorium to distilled water is poor, the effective use of thorium in water-cooled reactors would probably require the development of corrosion-resistant thorium alloys. Even then, the use of such metallic fuels would require evaluation with respect to thorium-uranium mixed oxide.

The primary objective of this work was to develop thorium alloys with good resistance to corrosion by distilled water at elevated temperatures. Because of the increasing importance of thorium-uranium alloys as possible reactor fuel, some investigation of thorium-uranium alloys was included in this study.

Data $(1,2,3)$ released by various investigators on the aqueous corrosion of thorium are in considerable disagreement. Those results that 
exist are questionable as to purity of the metal tested. Little information is available on the corrosion resistance of thorium alloys in water at temperatures above $200^{\circ} \mathrm{C}$.

Results presented here are preliminary. No detailed study was made. These initial results may be useful in possible future work on this subject.

\section{EXPERIMENTAL PROCEDURE}

Pure thorium (iodide crystal bar) and high-grade alloying elements were used in the preparation of thorium alloys. Impure thorium (calciumreduced) was included only for comparison purposes. Analyses of these materials (thorium) are included in Table I.

Table I

ANALYSES OF THORIUM

\begin{tabular}{|c|c|c|c|c|c|c|c|c|c|c|c|c|c|}
\hline \multirow{2}{*}{ Material } & \multicolumn{10}{|c|}{ Composition (ppm) } \\
\cline { 2 - 14 } & $\mathrm{C}$ & $\mathrm{N}$ & $\mathrm{O}$ & $\mathrm{Zr}$ & $\mathrm{Fe}$ & $\mathrm{Ni}$ & $\mathrm{W}$ & $\mathrm{Al}$ & $\mathrm{Cr}$ & $\mathrm{Cu}$ & $\mathrm{Si}$ & $\mathrm{Ca}$ & Other \\
\hline $\begin{array}{l}\text { Crystal-bar } \\
\text { Thorium, MH-2 }\end{array}$ & 36 & 10 & 35 & 50 & 40 & 0.8 & 1 & 40 & 5 & 4 & 50 & 5 & $\begin{array}{l}\text { Faint } \\
\text { traces }\end{array}$ \\
\hline $\begin{array}{l}\text { Calcium-reduced } \\
\text { Thorium, NLC-2 }\end{array}$ & 95 & 46 & 1205 & 3 & 400 & 200 & 2.0 & 60 & 85 & 40 & 50 & 100 & $\begin{array}{l}\text { Faint } \\
\text { traces }\end{array}$ \\
\hline
\end{tabular}

No analysis was obtained for the alloys; therefore all listed compositions are nominal.

Alloy buttons were made in an argon atmosphere by nonconsumable arc-melting on a water-cooled copper hearth. The buttons, weighing approximately 20 to $25 \mathrm{~g}$, were melted at least three times. Pure thorium and most of its alloys were reduced to a thickness of about $3.2 \mathrm{~mm}$ ( $1 / 8$ in.) by cold rolling.

Alloys were annealed for $2 \mathrm{hr}$ in vacuum at $850^{\circ} \mathrm{C}$ and furnacecooled. Impure thorium was used as received in plate form.

The corrosion tests were run in stainless-steel autoclaves, with the specimens supported by sapphire rods in a stainless-steel rack. These specimens were prepared and examined before and after each test, following the laboratory practice for high-temperature water-corrosion tests. The corrosion products formed from water-corroded thorium were removed ultrasonically in concentrated nitric acid at room temperature. However, corrosion products from the alloys were mechanically removed with a nylon toothbrush. 
In general, the new alloys were given a $24-\mathrm{hr}$ test in $150^{\circ} \mathrm{C}$ water. If the alloy did not disintegrate or show signs of early failure in this exposure, a longer exposure period or higher testing temperature was used.

\section{RESULTS AND DISCUSSION}

In the preliminary evaluation of unalloyed thorium, iodide thorium exhibited a uniform corrosion in distilled water at $125^{\circ} \mathrm{C}$, whereas, calciumreduced thorium showed an early, catastrophic, corrosion failure. At $150^{\circ} \mathrm{C}$, both materials were disintegrated within $96 \mathrm{hr}$. Since the calciumreduced thorium contains impurities of oxygen, iron, nickel, calcium, and carbon as high as $1200 \mathrm{ppm}$, the influence of these impurities on its corrosion resistance in high-temperature water was apparent. The maximum impurity of each of the above elements in iodide thorium was less than $50 \mathrm{ppm}$. As a result of these initial tests, iodide thorium was chosen for base stock in the preparation of thorium alloys.

The investigation of thorium alloys covered all potential alloying elements that showed good results in available literature. The alloying elements were also chosen on their possibility of forming insoluble intermetallic compounds. Nuclear properties, reactivity, and volatility were also considered.

\section{A. Thorium-Carbon Alloys}

Carbon is one of the main impurities found in thorium, the extent of contamination varying with the method of preparation. Thorium and carbon form two compounds, $\mathrm{ThC}$ and $\mathrm{ThC}_{2}$. The solid-solubility limit of carbon in thorium is temperature-dependent. The maximum solubility at $1215^{\circ} \mathrm{C}$ has been reported to be $0.91 \mathrm{w} /$ ocarbon. (4) The effect of carbon content on the corrosion behavior of thorium in high-temperature water is uncertain. Short-term corrosion tests indicated that the presence of carbon in a small amount seems desirable. Longer periods of observation up to 12 days in high-temperature water $\left(150\right.$ to $\left.200^{\circ} \mathrm{C}\right)$ revealed that thorium-carbon alloy often suffered intergranular penetration attacks. At $260^{\circ} \mathrm{C}$, all the thoriumcarbon binary alloys up to $1 \mathrm{w} / 0$ carbon suffered catastrophic corrosion failure within 6 days. The beta-to-alpha transformation in thorium appears to be lowered by niobium. (5) The transformation temperature is lowered because of the solubility of the metal in body-centered thorium, or because of the removal of impurities. Since carbon is one of the main impurities in thorium, the addition of niobium in thorium (in a small amount) may remove carbon from solid solution to form niobium carbides. A similar effect is expected with small additions of titanium and possibly iron. It was hoped that the addition of niobium, titanium, or iron would produce a continuous corrosion-resistant phase to protect thorium from high-temperature water attack. 
A series of thorium-carbon ternary alloys was arc-melted and tested in distilled water at $260^{\circ} \mathrm{C}\left(500^{\circ} \mathrm{F}\right)$. Alloy $\mathrm{Th}-0.5 \mathrm{w} / \mathrm{oC}-0.2 \mathrm{w} / \mathrm{oTi}$ showed the lowest corrosion rate. However, this alloy suffered an intergranular penetration attack after 12 days of exposure. Alloy Th-1w/oC$\mathrm{lw} / \mathrm{OTi}$ exhibited no apparent intergranular penetration after 3 and 6 days of exposure. The sample was split into two pieces after 12 days. Microscopic intergranular penetration attack was observed on the split areas. The results of this series of tests is summarized in Table II. It is apparent that the addition of titanium improved the corrosion life of $\mathrm{Th}-\mathrm{lw} / \mathrm{oC}$ and Th-0.5w/oC binary alloys. No favorable result was found with the addition of either niobium or iron.

Table II

CORROSION OF THORIUM-CARBON BASE ALLOYS IN WATER AT $260^{\circ} \mathrm{C}$

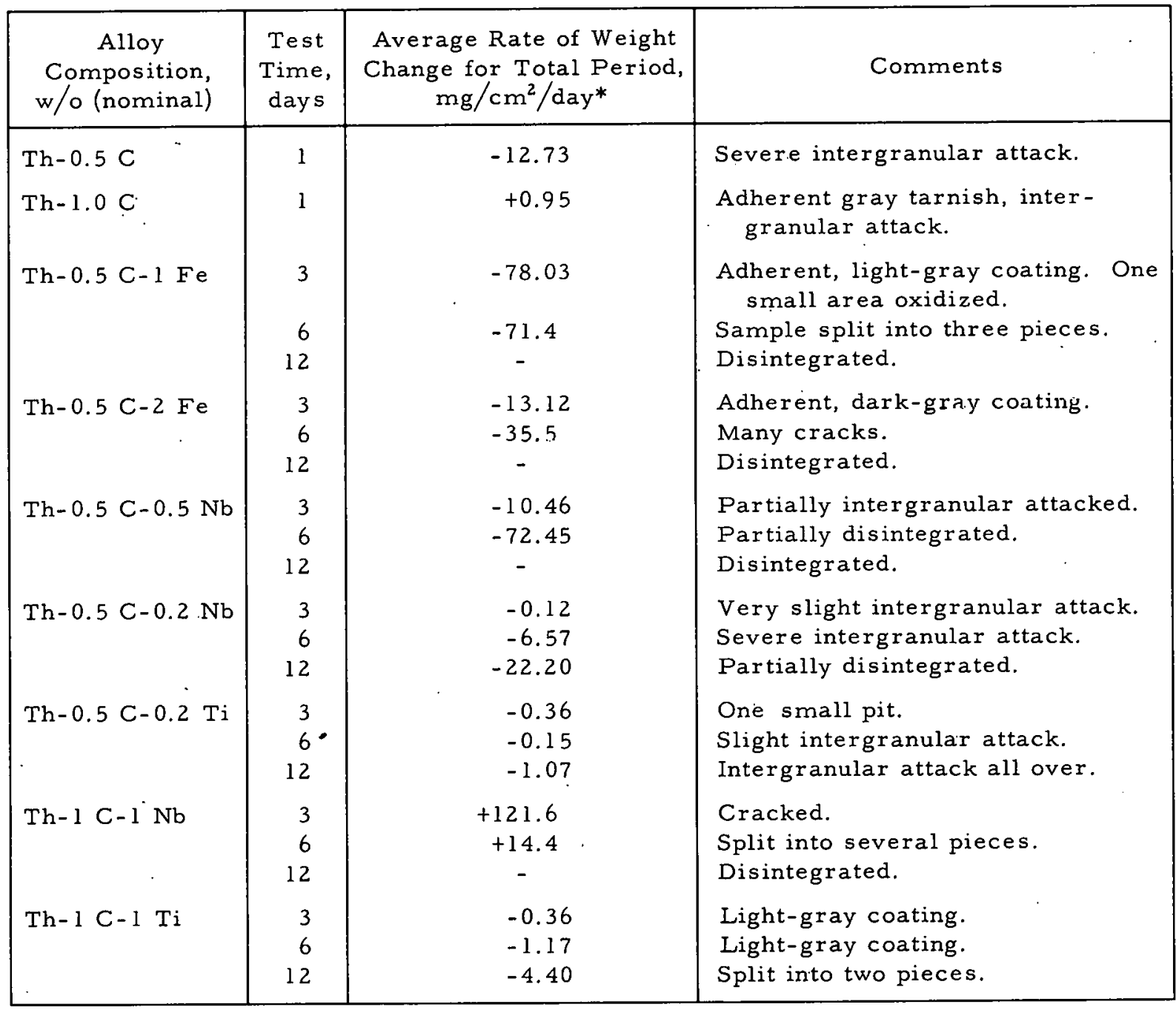

*"+" refers to weight gain; "-" refers to weight loss.

B. Thorium-Uranium Alloys

The solid solubility of uranium in thorium at room temperature is limited. (6) No intermetallic compound has been reported in this system. 
It is not anticipated that the addition of uranium to thorium would result in any significant improvement of the corrosion resistance of thorium. However, because of the importance of thorium-uranium alloys as possible reactor fuels, the corrosion behavior of these alloys was investigated.

A series of thorium-uranium alloys was arc-melted in increments of $5 \mathrm{w} / \mathrm{o}$ uranium in thorium up to the maximum of $40 \mathrm{w} / 0$ uranium. These alloys were exposed in distilled water at $150^{\circ} \mathrm{C}$ at different time intervals. Test results are recorded in Table III.

Table III

CORROSION OF THORIUM-URANIUM ALLOYS EXPOSED IN $150^{\circ} \mathrm{C}$ WATER

\begin{tabular}{|c|c|c|c|c|}
\hline \multirow{2}{*}{$\begin{array}{l}\text { Alloy Composition, } \\
\text { w/o (nominal) }\end{array}$} & \multicolumn{4}{|c|}{$\begin{array}{l}\text { Average Rate of Loss for } \\
\text { Total Period, } \mathrm{mg} / \mathrm{cm}^{2} / \mathrm{day}\end{array}$} \\
\hline & 2 Days & 4 Days & 7 Days & 12 Days \\
\hline Unalloyed Thorium 1 & 113.0 & - & - & - \\
\hline 2 & 111.0 & - & - & - \\
\hline$T h-5 \mathrm{U}$ & 25.8 & 77.6 & - & - \\
\hline Th- $10 \mathrm{U}$ & 18.2 & 63.5 & - &. \\
\hline Th- $15 \mathrm{U}$ & 47.1 & 64.0 & 67.8 & 74.6 \\
\hline$T h-20 \mathrm{U}$ & - & 98.3 & - & - \\
\hline Th-25U & 118.0 & 123.0 & - & - \\
\hline $\mathrm{Th}-30 \mathrm{U}$ & 115.0 & - & - & \\
\hline$T h-35 \mathrm{U}$ & 434.0 & 234.0 & - & \\
\hline $\mathrm{Th}-40 \mathrm{U}$ & 312.0 & 218.0 & - & \\
\hline
\end{tabular}

The thorium-uranium alloys exposed to $150^{\circ} \mathrm{C}$ water were characterized by an uneven and laminar attack. Corrosion products underneath the flakes could not be removed effectively. In most cases, corrosion rates could not be determined because of disintegration. However, after 7 days of exposure, thorium-15 w/o uranium alloy was the only survivor among the tested alloys. The rate of this alloy during 12 days' corrosion was $74.6 \mathrm{mg} / \mathrm{cm}^{2} /$ day.

On the basis of these test results, the ternary additions were investigated. Zirconium was chosen as the additive because of its good performance as a binary alloying element and because of its solubility in 
both thorium and uranium. The arc-melted thorium-15 w/o uranium alloy was prepared with the addition of 1,2 , and $4 \mathrm{w} / \mathrm{o}$ zirconium. All these alloys were annealed at $1000^{\circ} \mathrm{C}$ in an inert atmosphere for $24 \mathrm{hr}$ and then quenched in Wood's metal. It was hoped that this heat treatment would help to stabilize the gamma uranium-phase and consequently increase the corrosion resistance of these alloys.

The results of corrosion-testing in $200^{\circ} \mathrm{C}$ water are listed in Table IV. The addition of $4 \mathrm{w} / \mathrm{o}$ zirconium to thorium-15 w/o uranium apparently exhibited a beneficial effect. The sample was free from localized attack, while the 1 and $2 \mathrm{w} / \mathrm{o}$ zirconium alloys showed catastrophic corrosion failure within $24 \mathrm{hr}$.

Table IV

CORROSION OF THORIUM-URANIUM (BASE) ALLOYS EXPOSED IN $200^{\circ} \mathrm{C}$ WATER

\begin{tabular}{|c|c|c|c|}
\hline $\begin{array}{l}\text { Alloy Composition, } \\
\text { w/o (nominal) }\end{array}$ & $\begin{array}{l}\text { Test } \\
\text { Time, } \\
\text { days }\end{array}$ & $\begin{array}{c}\text { Average Rate of Loss } \\
\text { for Total Period, } \\
\mathrm{mg} / \mathrm{cm}^{2} / \text { day }\end{array}$ & Remarks \\
\hline $\mathrm{Th}-15 \mathrm{U}$ & 2 & 47.10 & At $150^{\circ} \mathrm{C}$ (data unavailable for $200^{\circ} \mathrm{C}$ ). \\
\hline$. \mathrm{Th}-15 \mathrm{U}-1 \mathrm{Zr}$ & $\mathbf{l}$ & - & Disintegrated. \\
\hline $\mathrm{Th}-15 \mathrm{U}-2 \mathrm{Zr}$ & 1 & - & Disintegrated. \\
\hline $\mathrm{Th}-15 \mathrm{U}-4 \mathrm{Zr}$ & 1 & 45.00 & $\begin{array}{l}\text { Specimen surface uniformly penetrated, } \\
\text { covered by a uniform powdery coating. }\end{array}$ \\
\hline Th-15U-4 Zr & 4 & 32.75 & $\begin{array}{l}\text { Specimen surface uniformly penetrated, } \\
\text { cuvered by a uniform powdery coating. }\end{array}$ \\
\hline$T h-15 U-4 \angle r$ & 7 & & $\begin{array}{l}\text { Specimen surface uniformly penetrated, } \\
\text { covered by a uniform powdery coating. }\end{array}$ \\
\hline Th- $15 \mathrm{U}-4 \mathrm{Zr}$ & 14 & 23.54 & $\begin{array}{l}\text { Specimen surface uniformly penetrated, } \\
\text { covered by a uniform powdery coating. }\end{array}$ \\
\hline
\end{tabular}

C. Miscellaneous Alloys

The thorium-aluminum alloys are attractive because aluminum has a favorable neutron cross section and is available at a low cost. However, there is little solubility of aluminum in thorium(7) at room temperature. At elevated temperatures, several intermetallic compounds have been reported. It is expected that thorium-rich aluminum alloys would probably be brittle owing to the presence of these compounds.

There are some indications in the literature that the addition of aluminum to thorium results in decreased corrosion resistance of thorium in water at 100 and $200^{\circ} \mathrm{C}$. Present test results in the temperature range between 150 and $260^{\circ} \mathrm{C}$ showed that alloying with aluminum between 3 and $7 \mathrm{w} / \mathrm{o}$ in thorium seems beneficial (Table V). However, the corrosion behavior for a much longer period of exposure remains to be seen. 
Table V

CORROSION OF MISCELLANEOUS THORIUM-BASE BINARY ALLOYS

\begin{tabular}{|c|c|c|c|c|}
\hline $\begin{array}{l}\text { Alloy Composition, } \\
\mathrm{w} / \mathrm{o} \text { (nominal) } \\
\end{array}$ & $\begin{array}{l}\text { T'est } \\
\text { Time, } \\
\text { days }\end{array}$ & $\begin{array}{l}\text { Test. } \\
\text { Temp, } \\
{ }^{\circ} \mathrm{C}\end{array}$ & $\begin{array}{c}\text { Average Rate of Change } \\
\text { for Total Period, } \\
\mathrm{mg} / \mathrm{cm}^{2} / \text { day }^{*}\end{array}$ & Remarks \\
\hline Th- I Al & 1 & 200 & -7.16 & Gray coating. \\
\hline Th- 3 & $\begin{array}{l}2 \\
1 \\
3\end{array}$ & $\begin{array}{l}150 \\
200 \\
200\end{array}$ & $\begin{array}{r}-0.02 \\
+0.17 \\
-313.00\end{array}$ & $\begin{array}{l}\text { Adherent, multicolor tarnish. } \\
\text { Adherent, dark blue-gray tarnish. } \\
\text { Partially disintegrated. }\end{array}$ \\
\hline $\mathrm{Th}-5 \mathrm{Al}$ & $\begin{array}{l}3 \\
1 \\
3\end{array}$ & $\begin{array}{l}200 \\
260 \\
260\end{array}$ & $\begin{array}{l}+0.036 \\
+1.99 \\
-\quad\end{array}$ & $\begin{array}{l}\text { Gray tarnish. } \\
\text { Adherent, gray translucent film. } \\
\text { Disintegrated. }\end{array}$ \\
\hline Th-7 Al & $\begin{array}{l}1 \\
6\end{array}$ & $\begin{array}{l}200 \\
200\end{array}$ & $\begin{array}{l}-1.13 \\
-\end{array}$ & $\begin{array}{l}\text { Gray tarnish. } \\
\text { Split into two pieces. }\end{array}$ \\
\hline Th-5 Y, & $\begin{array}{l}1 \\
1 \\
6\end{array}$ & $\begin{array}{l}150 \\
200 \\
200\end{array}$ & $\begin{array}{c}-0.25 \\
-36.4 \\
-\end{array}$ & $\begin{array}{l}\text { Adherent, smooth, gray-black coating. } \\
\text { Same type of coating as above, } \\
\text { except slightly rough surface. } \\
\text { Disintegrated. }\end{array}$ \\
\hline $\mathrm{Th}-1.0 \mathrm{Y}$ & $\begin{array}{l}1 \\
1\end{array}$ & $\begin{array}{l}200 \\
260\end{array}$ & $\begin{array}{l}-0.26 \\
-0.23\end{array}$ & $\begin{array}{l}\text { Light, brown-blue tarnish. } \\
\text { Slightly pitted. }\end{array}$ \\
\hline $\mathrm{Th}-1 \mathrm{Pd}$ & 2 & 150 & - & Disintegrated. \\
\hline $\mathrm{Th}-3 \mathrm{Pt}$ & 2 & 150 & - & Disintegrated. \\
\hline $\begin{array}{l}\text { Th-9 U.-2 Zr } \\
\vdots\end{array}$ & 2 & 150 & -3.93 & $\begin{array}{l}\text { Thin, slightly gray powder, over } \\
\text { adherent black coating. Sur- } \\
\text { face smooth. }\end{array}$ \\
\hline $\mathrm{Th}-5 \mathrm{Fe}$ & 2 & 200 & $\begin{array}{r}-1.09 \\
-89.7\end{array}$ & $\begin{array}{l}\text { Loose, rust-colored powder; covered, } \\
\text { adherent, dark-gray coating. Sur- } \\
\text { face sriuoth. } \\
\text { Adherent, slightly gray-green; } \\
\text { coating uniform. }\end{array}$ \\
\hline Th-9 U-2 Zr & 1 & 200 & -582.0 & Cracked and spalled. \\
\hline Th-5 Sn & 1 & 200 & - & Disintegrated. \\
\hline $\mathrm{Th}-3 \mathrm{Mo}$ & 1 & 200 & -449.0 & $\begin{array}{l}\text { Black loose powder. Surface } \\
\text { slightly rough. }\end{array}$ \\
\hline $\mathrm{Th}-3 \mathrm{~Pb}$ & 1 & 200 & -1.3 & Adherent, gray coating. \\
\hline $\mathrm{Th}-5 \mathrm{~Pb}$ & $\begin{array}{l}3 \\
7\end{array}$ & $\begin{array}{l}200 \\
200\end{array}$ & $\begin{array}{r}-0.41 \\
-66.20\end{array}$ & $\begin{array}{l}\text { Small pits. } \\
\text { Cracked. }\end{array}$ \\
\hline$T h=1 \mathrm{Ru}$ & 1 & 200 & - & Disintegrated. \\
\hline $\mathrm{Th}-5 \mathrm{Ti}$ & 6 & 200 & - & Disintegrated \\
\hline $\mathrm{Th}-10 \mathrm{Ti}$ & $\begin{array}{l}1 \\
6\end{array}$ & $\begin{array}{l}200 \\
200\end{array}$ & $\begin{array}{c}-26.20 \\
-\end{array}$ & $\begin{array}{l}\text { Cracked and pitted. } \\
\text { Disintegrated: }\end{array}$ \\
\hline Th-5 Zr & 6 & 200 & -25.40 & Unevenly attacked. \\
\hline $\mathrm{Th}-10 \mathrm{Zr}$ & $\begin{array}{l}1 \\
6\end{array}$ & $\begin{array}{l}200 \\
200\end{array}$ & $\begin{array}{l}-0.49 \\
-0.05\end{array}$ & $\begin{array}{l}\text { Gray tarnish. } \\
\text { Adherent, smooth, gray-black coating. }\end{array}$ \\
\hline $\mathrm{Th}-10 \mathrm{Ce}$ & 1 & 200 & - & Disintegrated. \\
\hline $\mathrm{Th}-10 \mathrm{Cr}$ & 1 & 200 & - & Disintegrated. \\
\hline $\mathrm{Th}-5 \mathrm{Nb}$ & 1 & 200 & - & Disintegrated. \\
\hline Th-5 Ni & 1 & 200 & - & Disintegrated. \\
\hline$T h-5 \mathrm{U}$ & 1 & 200 & - & Disintegrated. \\
\hline Th-2 V & 1 & 200 & - & Disintegrated. \\
\hline$T h-2 W$ & 1 & 200 & - & Disintegrated. \\
\hline
\end{tabular}

*"+" refers to weight gain; "-" refers to weight loss. 
There had only been scattered information regarding the thoriumyttrium system. Eash and Carlson $(8)$ have investigated this systern. Their diagram indicates that a: region of complete solid solubility exists at elcvated temperatures and a eutectoid reaction takes place at $1375^{\circ} \mathrm{C}$ and $25 \mathrm{w} / \mathrm{O}$ yttrium. The solid solubility limits in the $\alpha(\mathrm{Th})$ and $\alpha$ (Y) regions at room temperature are approximately $20 \mathrm{w} / \mathrm{o}$ yttrium and $70 \mathrm{w} / 0$ thorium, respectively. Since yttrium has a relatively low neutron cross section and has not: been investigated, alloying with yttrium seems justified.

Two alloys containing 5 and $10 \mathrm{w} / 0$ yttrium were arc-melted and tested as cast. Short-term tests revealed a significant improvement in the corrosion resistance of the thorium-10 w/o yttrium alloy.

Several other alloys were also tested for different reasons. It was not found advantageous to alloy with cathodic elements such as platinum and palladium. Addition of ruthenium or tin to thorium was catastrophic. Lead addition did not result in a good alloy. The thorium $-9 \mathrm{w} / 0$ uranium- $2 \mathrm{w} / 0$ zirconium alloy showed a high corrosion rate in distilled water at $200^{\circ} \mathrm{C}$.

D. The Removal of Corrosion Products from Water-corroded Thorium

During the early stages of this work, consistant corrosion rates were not obtainable when thorium samples were merely dried and weighed. Unsuccessful attempts were made to remove the corrosion products by polishing with a nonmetal-cutting cloth and by.brushing with various kinds of brushes: Solutions of the following acids were investigated, both with and without ultrasonic vibration: $\mathrm{HNO}_{3}, \mathrm{HF}, \mathrm{H}_{3} \mathrm{PO}_{4}, \mathrm{H}_{2} \mathrm{SO}_{4}, \mathrm{CrO}_{3}$, and $\mathrm{HCl}$. Of these, only, concentrated hydrofluoric acid, ultrasonically. treated, provided nearly satisfactory corrosion-product removal. Further investigation would be required for complete evaluation.

\section{ACKNOW LEDGMENT}

The author is indebted to Dr. J. E. Draley. for his many helpful advices, and to the late Mr. L. A. Hasenfang for the help given in conducting the experimental part of this work. 


\section{REFERENCES}

1. Draley, J. E., The Corrosion of Thorium - A Review of Project Literature, ANL-4908(Oct 1952).

2. Berry, W. E., H. A. Pray, and.R. S. Peoples, Corrosion of Thorium and Thorium Binary Alloys in Distilled Water at 100 and $200^{\circ} \mathrm{C}$, BMI-951 (Sept 1954).

3. Kneppel, D., Aqueous Corrosion of Thorium Alloys and Zircaloy-clad Thorium Alloys, NMI-1226 (March 1960).

4. Mickelson, R., and D. Peterson, Solubility of Carbon in Thorium, ISC-463. (Feb. 1954).

5. Carlson, O. N., J. M. Dickinson, H. E. Lunt, and J. Wilhelm, ThoriumColumbium and Thorium-Titanium Alloy. Systems, J. Metals $\underline{8}$, $132-136$ (Feb 1956).

6. Hansen, M., Constitution of Binary Alloys, McGraw-Hill Book Co., p. $1233(1958)$.

7. Ibid, pp. $138-139$.

8. Eash, D. T., and O. N. Carlson, Investigation of the Thorium-Yttrium System, Trans. ASM 52, 1097-1114(1960). 